\title{
Identification of potential insect vectors of the Cape Saint Paul Wilt Disease of coconut in Ghana by PCR
}

\author{
Fabian PILET ${ }^{1}$ \\ René PHILIPPE ${ }^{1}$ \\ Simon REIGNARD ${ }^{1}$ \\ Sophie DESCAMPS ${ }^{1}$ \\ Robert QUAICOE ${ }^{2}$ \\ Joe NKANSA-POKU ${ }^{2}$ \\ Sandrine FABRE \\ Michel DOLLET ${ }^{1}$ \\ ${ }^{1}$ CIRAD, Département BIOS, UPR29, \\ Campus international de Baillarguet, \\ 34398 Montpellier, France \\ $<$ fabian.pilet@cirad.fr> \\ ${ }^{2}$ OPRI, Coconut Programme, \\ P.O. Box 245, Sekondi, Ghana
}

\section{Introduction}

Lethal yellowing is the most damaging coconut disease in West Africa (Chana, Nigeria and Togo) [1]. The disease was first observed in Chana in 1932 and is locally called Cape Saint Paul Wilt (CSPW). As other coconut lethal yellowing diseases around the world, the CSPW disease is caused by a phytoplasma, cell wallless bacteria which inhabit the phloem sieve elements. This location inside the plant and the obligate host status of the Phytoplasma implies they can be transmitted and spread mainly by insect vectors that are leafhoppers and planthoppers. In fact, all the known phytoplasmas insect vectors are Auchenorrhyncha family members to date.

Myndus crudus (Homoptera: Cixiidae) has been identified as the vector of the coconut $\mathrm{LY}$ in Florida [2]. Because of the similitude between the LY and the CSPW disease, and the presence of one insect of the same genera very common on coconut in Ghana, Myndus adiopodoumeensis has been suspected to be the vector in Chana [3]. However, transmission trials by introducing numbers of Myndus adiopodoumeensis in cages have not resulted in the production of the disease in coconut plants to date [4]. Introductions of other common species on coconut (mainly Derbidae) in transmission cages have not also reproduce the disease in palms.

\begin{abstract}
The vector of the phytoplasma responsible for the coconut lethal yellowing disease in West Africa is unknown to date. However, it is known that phytoplasmas are transmitted by leafhoppers and planthoppers, which are supposed to be the only ones able to inject the phytoplasma in the phloem. Whereas the presence of phytoplasma in the insect does not prove its capacity to transmit the disease. We have tested a large number of insects for the presence of phytoplamas by PCR (direct PCR and Nested P(R) using both primer pairs specific for all phytoplasmas and those specific for the coconut lethal yellowing disease phytoplasma. In effect the evidence of one or several species carrying the phytoplasma would direct us on the insects to focus on in our transmission cages trials.
\end{abstract}

Key words: coconut, phytoplasma, lethal yellowing disease, CSPW disease, insect vectors
Phytoplasma can be detected in the insect vector by direct PCR $[5,6]$ or Nested PCR. However, presence of phytoplasma in one insect does not prove that it is the vector. The phytoplasmas can be ingested by the insect during feeding, but fail to be acquired (i.e. passage through the intestinal wall into the haemolymph, multiplication and then accumulation in the salivary glands) for transmission. However, detection of the phytoplasma can give some important indication about the status of the insect towards the phytoplasma.

The aim of this study was to check the presence of phytoplasma i) in the insect species that have been introduced in the transmission cages, ii) in all planthoppers and leafhoppers found in and around coconut plot.

\section{Materials and methods}

\section{Collection of insects}

Insects were collected from a plot of Malayan Yellow Dwarf $\times$ Vanuatu Tall hybrid coconut planted in June 2001 at Asebu, Ghana, where coconut trees showing lethal yellowing disease symptoms can be observed since April 2005. Three series of collections have been realized. The first collection, which corresponded mainly to the same insects species introduced into transmission cages, was done on coconut leaves of both healthy and diseased coconut trees. The most common species were bulked in tubes of five insects per species, whereas the rarer species were bulked in tubes of one to five insects according their size.

The second series consisted of collection of insects by "sweeping the grasses" in the plot with sweeping net. Insects of each species were bulked into specific tubes of one to five insects according their size and their frequencies.

The third series consisted of collection of all Auchenorrhyncha, during both the day and the night on diseased coconut, and other crops such Citrus and Oil Palm growing around the plot as exhaustive.

Some Aleurodidae, Aphididae and Pseudococcidae were collected from coconut trees too.

\section{Extraction of insect DNA}

DNA was extracted from insects according to the protocol of Maixner et al. [5] with the following minor modification. Insects were ground in $400 \mu \mathrm{L}$ of extraction buffer $[100 \mathrm{mM}$ Tris- $\mathrm{HCl}$ at $\mathrm{pH} 8.0,2 \%$ cetyltrimethylammonium bromide, $1.4 \mathrm{M} \mathrm{NaCl}, 20 \mathrm{mM}$ ethylenediaminetetraacetic acid (EDTA) and 2\% polyvinyl pyrrolidone], and the slurry was incubated for $60 \mathrm{~min}$ at $65^{\circ} \mathrm{C}$. After incubation, an equal volume of chloroform-isoamyl alcohol (24:1) was added and centrifuged for $20 \mathrm{~min}$ at $12000 \mathrm{~g}$. The supernatant was collected and the nucleic acid 
precipitated with an equal volume of isopropanol. Following a $30 \mathrm{~min}$ incubation at $4{ }^{\circ} \mathrm{C}$, the DNA was pelleted at $12,000 \mathrm{~g}$ for $20 \mathrm{~min}$ and the pellet washed with $70 \%$ ethanol and resuspended in 25 to $100 \mu \mathrm{L}$ of $\mathrm{TE}(\mathrm{pH} 8.0)$.

\section{PCR analyses}

The detection of phytoplasmas in insect DNA was performed using direct PCR with the phytoplasma universal primers P1(5'-AAGAGTITGATCCTGGCTCA GGATT-3')/P7 (5'CGTCСТTCATCGGСTCTT-3') derived from 16 SrDNA [7]. A sample of $2 \mu \mathrm{L}$ of template DNA solution was used in a PCR reaction mixture $(25 \mu \mathrm{L})$. Positive samples using P1/P7 were checked using the specific CSPWD primers [8] G813 (5'-CTAAGTGTCGGGGGTTTCC-3')/ GAKSR (5'-TTGAATAAGAGGAATATGG-3'), corresponding in the primer AKSR modified [9] whereas some negative samples were controlled by nested PCR. For nested PCR assays, $2 \mu \mathrm{L}$ of direct PCR P1/P7 product were used as template DNAs and the PCR performed using the specific CSPWD primers G813/
GAKSR. The PCR products were analyzed by electrophoresis through $0.8 \%$ agarose gel and stained with ethidium bromide and exposed to ultraviolet light. The size of the PCR products was estimated by the GelPilot $1 \mathrm{~Kb}$ Plus Ladder (Qiagen) as standard marker.

\section{Data analyses}

Any samples showing one visible band around the expected size was considered positive. With P1/P7 primers, that is expected to give a product of $1750 \mathrm{bp}$, samples showing one band from 1,600 to 1,900 bp have been marked as positive. Both G813/GAKSR and nested PCR products showing one band in the $800-1,000$ bp range (expected size of $900 \mathrm{bp}$ ) were considered positive.

\section{Results}

A total of 12,549 insects representing 2,157 batches, and distributed among 203 species of 19 families were collected (table 1). To date, 1683 of those batches have been already checked by PCR P1/P7 and 126 of them have shown one band closed to the expected size. However, none of those positive samples was positive using the specific CSPW primers (table 1).

Half of the tested insects were part of the species which were introduced into the transmission cages [4] and correspond mainly to the most common species observed on coconut, and are detailed in the table 2. Some bands were observed with P1/P7 for some of the species screened such as Diostrombus mayumbensis and Metaphenice stellulata both Derbidae, but no band was observed for the candidate Myndus adiopodoumeensis, whatever the primer-pair used. Among the positive samples, none turned out positive by using the CSPW primers. However, one tube among 174 (862 insects tested) of Diostrombus mayumbensis was tested positive by nested PCR. While most of the P1/.P7 PCR products were of low intensity, three samples were remarkable because of the high intensity of the bands observed. These three samples were one batch (22B 1347) of large Cicadellidae (LGC), containing 4

Table 1. Number of batches (N B), Number of insects collected (NI) and number of positive batches (presence of band) of insects on the number of batches of insect tested for the PCR P1/P7, PCR G813/GAKSR and nested PCR for each family and subfamily collected in the field. (LCC = Large Cicadellidae; SMC = Small Cicadellidae; ND = Not Determinated).

\begin{tabular}{|c|c|c|c|c|c|c|c|}
\hline Family & Subfamily & Species & N B & N I & PCR P1/P7 & PCR G813/GAKSR & Nested PCF \\
\hline Achilidae & & 2 & 3 & 11 & $1 / 2$ & $0 / 2$ & $0 / 1$ \\
\hline Aleurodidae & Aphidinae & 1 & 65 & 643 & $0 / 65$ & $0 / 2$ & $0 / 8$ \\
\hline Aphididae & Hormaphidinae & 1 & 57 & 2843 & $9 / 57$ & $0 / 19$ & $0 / 3$ \\
\hline Aphrophoridae & & 2 & 87 & 101 & $0 / 29$ & & $0 / 8$ \\
\hline Cercopidae & & 2 & 43 & 44 & $0 / 33$ & & $0 / 0$ \\
\hline \multirow{11}{*}{ Cicadellidae } & Achilidae & 1 & 2 & 3 & $0 / 1$ & & $0 / 1$ \\
\hline & Agalliinae & 3 & 12 & 40 & $0 / 12$ & $0 / 2$ & $0 / 2$ \\
\hline & Cicadellinae & 2 & 55 & 171 & $2 / 55$ & $0 / 2$ & $0 / 7$ \\
\hline & Deltocephalinae & 18 & 163 & 577 & $4 / 160$ & $0 / 28$ & $0 / 63$ \\
\hline & Gyponinae & 1 & 35 & 83 & $1 / 9$ & $0 / 4$ & $0 / 4$ \\
\hline & Hecalinae & 1 & 78 & 232 & $0 / 77$ & & $0 / 4$ \\
\hline & Paraboloponinae & 1 & 1 & 3 & $0 / 1$ & $0 / 1$ & $0 / 0$ \\
\hline & Typhlocybinae & 2 & 11 & 40 & $0 / 11$ & & $0 / 2$ \\
\hline & LGC & ND & 46 & 222 & $5 / 44$ & $0 / 4$ & $0 / 4$ \\
\hline & SMC & ND & 35 & 171 & $0 / 32$ & $0 / 2$ & $0 / 4$ \\
\hline & Undertermined & 95 & 172 & 403 & $0 / 130$ & $0 / 6$ & $0 / 116$ \\
\hline Cixiidae & & 5 & 141 & 665 & $0 / 83$ & $0 / 2$ & $0 / 11$ \\
\hline Delphacidae & & 19 & 58 & 189 & $3 / 47$ & $0 / 7$ & $0 / 22$ \\
\hline Derbidae & & 18 & 848 & 4,266 & $94 / 668$ & $0 / 61$ & $1 / 267$ \\
\hline Dictyopharidae & & 1 & 1 & 1 & $0 / 1$ & & $0 / 1$ \\
\hline Flatidae & & 1 & 23 & 43 & $0 / 7$ & & $0 / 4$ \\
\hline Lophopidae & & 1 & 7 & 31 & $0 / 1$ & & \\
\hline Menoplidae & & 5 & 74 & 336 & $0 / 60$ & & $0 / 51$ \\
\hline Pentatomidae & & 13 & 86 & 87 & $6 / 45$ & $0 / 3$ & $0 / 14$ \\
\hline Pseudococcidae & & 2 & 5 & 19 & $0 / 4$ & $1 / 3$ & $0 / 1$ \\
\hline Ricaniidae & & 2 & 5 & 21 & $0 / 5$ & $0 / 4$ & $0 / 1$ \\
\hline Thripidae & & 1 & 28 & 1,267 & $0 / 28$ & & \\
\hline Tingidae & & 1 & 3 & 3 & $0 / 3$ & $0 / 1$ & $0 / 2$ \\
\hline Tropiduchidae & & 2 & 13 & 34 & $1 / 13$ & & $0 / 13$ \\
\hline Total & & 203 & 2,157 & 12,549 & $126 / 1,683$ & $1 / 153$ & $1 / 614$ \\
\hline
\end{tabular}


Table 2. Number of batches (N B), Number of insects collected (NI) and number of positive batches (presence of band) of insects on the number of batches of insect tested for the PCR P1/P7, PCR G813/GAKSR and nested PCR for the most common species observed on coconut at Asebu, Chana. (LGC = Large Cicadellidae; SMC = Small Cicadellidae).

\begin{tabular}{|c|c|c|c|c|c|c|}
\hline Family & Species & N B & N I & PCR P1P7 & PCR G813/GAKSR & Nested PCR \\
\hline Cixiidae & Myndus adiopodoumeensis & 131 & 645 & $0 / 80$ & $0 / 2$ & $0 / 8$ \\
\hline \multirow[t]{2}{*}{ Cicadellidae } & LGC & 46 & 222 & $5 / 44$ & $0 / 4$ & $0 / 4$ \\
\hline & SMC & 35 & 171 & $0 / 32$ & $0 / 2$ & $0 / 4$ \\
\hline \multirow[t]{9}{*}{ Derbidae } & Diostrombus annetti & 43 & 212 & $0 / 23$ & $0 / 1$ & $0 / 23$ \\
\hline & Diostrombus dilattatus & 98 & 479 & $6 / 97$ & $0 / 5$ & $0 / 8$ \\
\hline & Diostrombus luteus & 24 & 88 & $1 / 24$ & $0 / 2$ & $0 / 4$ \\
\hline & Diostrombus mayumbensis & 250 & 1239 & $35 / 184$ & $0 / 9$ & $1 / 174$ \\
\hline & Diostrombus nitida & 79 & 388 & $15 / 79$ & $0 / 12$ & $0 / 9$ \\
\hline & Metaphenice stellulata & 139 & 683 & $23 / 88$ & $0 / 19$ & $0 / 13$ \\
\hline & Patara armara & 141 & 698 & $8 / 98$ & $0 / 6$ & $0 / 10$ \\
\hline & Metaphenice stellulata larve & 38 & 339 & $6 / 43$ & & \\
\hline & Proutista fritillaris & 24 & 112 & $0 / 20$ & $0 / 7$ & $0 / 18$ \\
\hline Menoplidae & Nibia nervosa & 24 & 114 & $0 / 15$ & & $0 / 11$ \\
\hline Total & & 1,072 & 5,390 & $99 / 827$ & $0 / 69$ & $1 / 286$ \\
\hline
\end{tabular}

specimens of Goniagnathus obesus obesus (Deltocephalinae: (icadellidae) and one undetermined Cicadellidae (C11), one batch (C32-1 0108) among 42 (representing 175 insects) of Recilia canga (Cicadellidae: Deltocephalinae), and one batch of Numicia damocles (Tropiduchidae).

\section{Discussion}

The very high diversity of Auchenorrhycha observed at Asebu, Ghana, confirm the necessity of this study. In fact, to date mainly the common species have been introduced in transmission cages but introduction of all the 208 species met cannot be envisaged.

The first important result consists of the absence of phytoplasma in Myndus adiopodou- meensis. Introduction of this species in transmission cage did not result in the transmission of the disease [4]. While Myndus adiopodoumeensis has been the main suspected vector of the CSPW disease [10], those two results do not seem to support this hypothesis.

Because nested PCR is a very sensitive tool, it is difficult to conclude about the presence of the CSPW phytoplasma in one Diostrombus mayumbensis. The fact that it has been detected only by nested PCR reveal a low concentration of phytoplasma. This low concentration can just correspond to the ingestion of phytoplasma during feeding and does not give any indication about the capacity of the phytoplasma to multiply inside this insect. This result needs more investigation by using other tech- niques such Quantitative-PCR to evaluate the exact concentration of phytoplasma in the insect.

One of the three samples showing a band of high intensity by direct PCR using P1/P7 primers contains Recilia canga. Because Recilia canga belongs to the sub-family of Deltocephalinae (Cicadellidae), which contains the highest number of known phytoplasma vectors [11] and Recilia mica is the vector of the blast disease of oil palm nurseries [12], this positive result is probably due to a phytoplasma. However, the negative result using G813/GAKSR exclude the LY phytoplasma, as for the tube containing Goniagnathus obesus obesus (Deltocephalinae) and Numicia damocles (Tropiduchidae). These three samples will be sequenced.

Table 3. Number of batches (N B), Number of insects collected (N I) and number of positive batches (presence of band) of insects on the number of batches of insect tested for the PCR P1/P7, PCR G813/GAKSR and nested PCR for the Cicadellidae: Deltocephalinae.

\begin{tabular}{|c|c|c|c|c|c|}
\hline Species & N B & N I & PCR P1/P7 & PCR G813/GAKSR & Nested PCR \\
\hline Balclutha aff. dufela & 1 & 5 & $0 / 1$ & $0 / 1$ & $0 / 1$ \\
\hline Balclutha dufela & 6 & 22 & $1 / 6$ & $0 / 1$ & $0 / 1$ \\
\hline Balclutha incisa & 15 & 68 & $0 / 15$ & $0 / 14$ & $0 / 13$ \\
\hline Balclutha sp & 3 & 10 & $1 / 3$ & $0 / 1$ & \\
\hline $\mathrm{C11}$ & 1 & 3 & $0 / 1$ & & $0 / 1$ \\
\hline C15 & 4 & 15 & $0 / 4$ & & \\
\hline $\mathrm{C} 26$ & 1 & 5 & $0 / 1$ & & \\
\hline C30 & 4 & 9 & $0 / 2$ & & \\
\hline$C 7$ & 1 & 2 & $0 / 1$ & & \\
\hline C92 & 4 & 19 & $0 / 4$ & $0 / 4$ & $0 / 1$ \\
\hline C93 & 3 & 8 & $0 / 3$ & & $0 / 3$ \\
\hline Exitianus occidentalis & 20 & 59 & $0 / 20$ & & $0 / 1$ \\
\hline Exitianus sp. & 1 & 3 & $0 / 1$ & $0 / 1$ & \\
\hline Goniagnathus obesus obesus & 26 & 52 & $0 / 26$ & & $0 / 13$ \\
\hline Recilia canga & 42 & 175 & $2 / 42$ & $0 / 5$ & $0 / 27$ \\
\hline Recilia lactipennis & 24 & 108 & $0 / 24$ & $0 / 1$ & $0 / 2$ \\
\hline Exitianus capicola & 6 & 13 & $0 / 6$ & & \\
\hline Cicadulina mbila & 1 & 1 & $0 / 1$ & & $0 / 1$ \\
\hline
\end{tabular}


To date, no CSPW phytoplasma has been detected by direct PCR with both the P1/P7 and G813/GAKSR primers pair even in Derbidae or Meenoplidae as observed by Mpunami et al. [6], even though those insects were mainly collected on coconut. It is not the case of some Cicadellidae sub-families like the Deltocephalinae which were captured by sweeping or "light-attraction". The percentage of those insects which have fed on coconut and moreover on diseased coconut is unknown. Also, some species of this sub-family have so far been collected in low numbers as presented in table 3. Because the known vectors of phytoplasma are predominantly among the Deltocephalinae sub-family [11], the investigation must be continued.

While bands have been observed by direct PCR in some insects, it is still necessary to check by nested PCR. Some samples of insects were composed of only one very small insect, in which case DNA yield would be low during the extraction, or if the insect was collected before the process of acquisition of the pathogen was completed, then only the nested PCR would be able to detect the phytoplasma, even if the result has to be considered with caution.

Acknowledgement. This research was funding by the French Ministry of Foreign Affairs through the FSP 2004-34 (Agronomical research in Ghana in the area of perennial and food crop cultivation). We thank Jacques Bon- fils, Thierry Mateille (IRD) and Jean-François Germain (LNPV) for determining all the species collected.

\section{REFERENCES}

1. Dery SK, N'Cho YP, Sangare A, Arkhurst ED. Cape Saint Paul Wilt Disease of coconut in Ghana. In: Eden-Green SJ, Ofori F (Eds.), Proceedings of an International Workshop on lethal yellowing-like disease of coconut, Elmina, Ghana, November 1995. Chatman, UK: Natural Resources Institute, p. 147-151, 1997.

2. Howard FW, Norris RC, Thomas DL. Evidence of transmission of palm lethal yellowing agent by a planthopper, Myndus crudus (Homoptera, Cixiidae). Tropical Agriculture 1983; 60: 168-71.

3. Dery SK, Philippe R, Mariau D. Auchenorrhyncha (Homoptera), suspected vectors of coconut lethal yellowing disease in Ghana. Plantations, Recherche, Developpement 1996; $3: 355-63$.

4. Philippe R, Nkansah JP, Fabre S, Quaicoe R, Pilet F, Dollet M. Search for the vector of Cape Saint Paul wilt (coconut lethal yellowing) in Ghana. Bull Insectol 2007 ; 60 : 179-80.

5. Maixner M, Ahrens U, Seemuller E. Detection of the German grapevine yellows (Vergilbungskrankheit) MLO in grapevine, alternative hosts and a vector by a specific PCR procedure. Eur J Plant Pathol 1995 ; 101 : 241-50.
6. Mpunami A, Tymon A, Jones P, Dickinson MJ. Identification of potential vectors of the coconut lethal disease phytoplasma. Plant Pathol $2000 ; 49: 355-61$.

7. Smart $C D$, Schneider B, Blomquist $C L$, Guerra LJ, Harrison NA. Phytoplasma-specific PCR primers based on sequences of the 16S-23S rRNa spacer region. Appl Environ Microbiol 1996; $62: 2988-93$.

8. Tymon AM, Jones P, Harrison NA. Phylogenetic relationships of coconut phytoplasmas and the development of specific oligonucleotide PCR primers. Ann Appl Biol 1998 ; 132 : 437-52.

9. Dollet M, Fabre S, Pilet F, Quaicoe R, Mugini JA, Rassaby L. Variability and diagnosis of coconut lethal yellowing Syndromes in Africa. In: 16th International Congress International Organization for Mycoplasmology (IOM) - Cambridge, United Kingdom. 9-14 July 2006.

10. Dery KS, Philippe R, Mariau D. Auchenorrhyncha (Homoptera), suspected vectors of coconut lethal yellowing disease in Ghana. Plantations, Recherche, Developpement 1996 ; $3: 355-63$.

11. Weintraub PG, Beanland L. Insect vectors of phytoplasmas. Annu Rev Entomol 2006; 51 : 91-111.

12. de Chenon RD. Demonstration of the role of Recilia mica Kramer (Homoptera, Cicadellidae, Deltocephalinae) in the blast disease of oil palm nurseries in the Ivory Coast. Oleagineux $1979 ; 34: 113-5$. 